Article

\title{
Focus on Weaknesses or Strengths? Determining Factors for an Inclusive and Relational Management in Public Community Social Service Organizations
}

\author{
Germán Jaraíz Arroyo *(i) and Auxiliadora González Portillo * \\ Department of Social Work and Social Services, Universidad Pablo de Olavide, 41930 Sevilla, Spain \\ * Correspondence: gjararr@upo.es (G.J.A.); magonpor@upo.es (A.G.P.); Tel.: +34-628-435-666 (G.J.A.)
}

Received: 2 November 2020; Accepted: 13 December 2020; Published: 17 December 2020

\begin{abstract}
This article, which is result of a research and development (R\&D) project financed by the Spanish administration, studies the difficulties in managing social inclusion programs in Social Service (SS) Centers located in areas with high rates of exclusion in Andalusia (Spain). The research follows a qualitative methodology, based on observation, semi-open interviews (SOI), and focus groups (FG) aimed at the different actors in four Social Service Centers. Three dimensions are addressed: normative, functional, and perceived. The main results are four groups of incident factors: the mismatch between the expectations of non-professional actors (politicians, etc.) and those of technicians; the knowledge management of implemented dynamics; the position of the SS in local action networks; and the professional-client relationship. We concluded that, although these programs should be managed in an inclusive context, they are conditioned by scenarios with little possibility of social activation and a high level of interference and additional demands. Aspects that generate a great deal of organizational pressure divert professional practices to social assistance work.
\end{abstract}

Keywords: Social Services; social inclusion; management; professional practice; accompaniment; activation

\section{Introduction and Description of the Problem}

The Community Social Services (SS.SS, for its acronym in Spanish) were created in Spain in the 1980s to be a tool that allowed a newly inaugurated democracy to address the deficits of autonomy and social integration of citizens. These services aimed to overcome the Franco era's paternalistic model of social action and produce a new approach to intervention, based on the guarantee of social rights and integrative responses. As in other Mediterranean countries, they are designed as a decentralized policy [1]. In the case of Spain, the different regions have planning powers for these services, and the municipalities are responsible for their management.

The main features of SS.SS, in the case of the region of Andalusia, are as follows:

- A network of 336 centers with a presence in municipalities and city districts [2]. These SS.SS carry out the first social attention, receiving the demands of the clients, studying and evaluating the situations, and establishing an intervention plan to carry out the satisfaction of those demands, referring to specialized services when necessary.

- These centers have four programs in order to attend to the different needs: (1) Information, valuation, and orientation, which is in charge of the first access of the clients, the study of the situations and the derivation according to them; (2) attention to dependency, focused on problems related to ageing, social care, home care, etc.; (3) social cooperation and volunteering, whose relations with the community promote voluntary work and coordination with third sector entities; (4) cohabitation and social reintegration, whose mission is to provide social support 
and accompaniment in situations of conflict, vulnerability, and social exclusion. It is this fourth program that is specifically aimed at for social inclusion.

- In addition to material or economic benefits, SS.SS clients have guaranteed technical benefits, through teams formed by social workers, psychologists, and educators.

- The professional intervention aims to promote relationships of support for individuals and families lacking autonomy or social integration to facilitate their inclusion.

The SS.SS's approach to action have pivoted between two epistemological positions [3]: A focus on weaknesses, based mainly on specific responses and specifically adapted to the pathology of the client. A second position focused on strengths, where activating the capacities of clients and the environment itself [4] are the center of action. Both positions involve different sets of power relations between professional and client, different professional praxis, and organizational environments.

Following the Lisbon Summit in 2000, the debate on the impact of inclusion policies in Europe emerged, reinforcing the commitment to integration and, in particular, activation, understood as promoting the participation of subjects in the different vital spheres [5], but especially in the productive sphere through employment [6]. These guidelines reinforce the strategies to combat exclusion centered on strengths [7].

Andalusia places the SS.SS at the center of its strategy [8]. The strategy follows an inclusive approach whose objectives are twofold, on the one hand integration (centered on the idea of normalization) and on the other activation (in a double sense, social and labor). This inclusive approach is based on methodologies of accompaniment, understood as a temporary process of work between professional and client, thus requiring the subject's participation [9]. For this purpose, the tool used will be the personalized inclusion itinerary, which is an open protocol for professionals and clients to establish commitments and milestones, as well as to help the relationship process [10]. In Figure 1, we outline this inclusive approach. A second element of this regional strategy to SS.SS is the leadership of local inclusion networks.

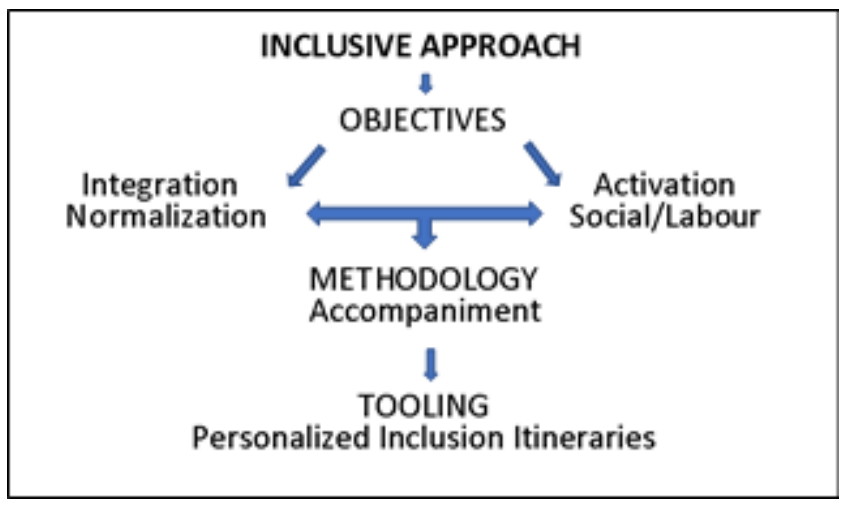

Figure 1. Outline of the inclusive approach. Source: own research.

However, despite regulatory clarification and budgetary efforts, the different actors involved (e.g., politicians, professionals, citizens) noted that the 2008 economic crisis blocked this re-focus of social intervention [10]. The most frequent argument used to a explain this is the over-demand on SS.SS services [11,12]. Between 2007 and 2016, the volume of requests grew by $26.7 \%$, most of which required urgent responses to evictions and withdrawals of electricity supply [13]. This also forced us to redirect resources from support programs to assistance programs, thus heavily compromising professional work.

The increase in requests for reports and procedures from other systems must be added to this: Prosecution (e.g., juvenile cases, evictions), education (e.g., school meals, absenteeism...), and culture (e.g., free recreational activities), all of which reinforces the role of information-control over accompaniment by SS.SS. 
Clearly, demand is the main barrier against the implementation of accompanying methodologies, but in a thorough analysis we noted that the decline in conditions had been brewing prior to the crisis and, therefore, the problem should not be understood exclusively from factors of demand and financing. A significant number of professionals consider that there were different elements already at play before the crisis that limited the accompaniment. In this study, we asked: What other factors hinder the adoption of an inclusive approach? To achieve this, we opted for qualitative research work on SS.SS located in vulnerable neighborhoods of Andalusian cities with high rates of social exclusion.

\section{Objectives and Methodology}

We proposed two specific research objectives: The first was to describe the operational conception of accompaniment to inclusion in SS.SS. The second was to identify the processes that in practice conditioned the adoption of these intervention methodologies.

The fieldwork was developed between the months of October 2018 and March 2019 in four SS.SS centers located in areas with high rates of exclusion in Andalusia (24 areas had this qualification in the region). The four centers are included in the catalogue of areas with high rates of exclusion defined by the Social Inclusion Plan of Andalusian Government [8]. This catalogue uses five regional indicators (i.e., economic poverty, school failure, unemployment, housing quality, and morbidity) to identify exclusion areas within two standard deviations from the regional average. In this sense, it must be clarified that this field work did not intend a proportional representation, but a qualified one [14]. The selection of information is based on the criteria of relevance of the discourses in relation to the subject of study, reiteration (of codes), and coincidence of diverse actors, according to a codification process that we will explain later.

Considering the objectives set out above, we opted for a qualitative approach focused on the perceived dimension [15,16] following Morel's public policy analysis proposal [17] and taking into account the substantives (norms, guidelines, and organizational criteria of the SS.SS), discursive (perceptions of the different actors), and operative (practices and perceived impacts).

In order to obtain this information, we used predefined techniques (i.e., semi-open interviews and focus groups) and open-ended ones (i.e., participant observation).

Participant observation was permanent throughout the field work ( 6 months) thanks to the presence of researchers at different points during the lifecycle of the centers (attendance to work meetings, training spaces, informal conversations with professionals and clients, etc.). All of this information was recorded in researchers' field journals and then organized into memos, which were especially useful for the discussion phase as they respected the contrast between observation and theory [18].

When carrying out semi-open interviews (SOI), we tried to approach the different perspectives with consideration for the subject of study, so it was necessary to design a balanced sample that would contemplate all the actors that participated in these policies, whether they designed them (politicians), execute them (professionals) or received them (clients and citizens). The political and professional informants (Table 1) were selected by qualified sampling [14]. Regarding professionals, we used the following selection criterion: management and direct intervention professionals with a minimum of two years' experience. For policymakers, we focused on informants involved in direct management of the centers (grassroots politicians), avoiding possible conflicts of interest. In the case of customers, the snowball procedure was used. A total of 12 interviews were conducted with an average duration of $45 \mathrm{~min}$. The coding followed in order to identify the speeches of the different actors throughout the text ifocus as follows: Politicians (SOI 1-2), direct intervention professionals (SOI 3-8), clients (SOI 9-12).

For the design of the interview, the standardized non-scheduled interview model was followed [19], allowing the interviewer to adapt the formulation and the order of the questions. Each interview had a common script and a specific section according to the characteristics of each group of informants. The scripts were structured in four blocks and adapted to each type of actor: vision of exclusion and responses to it, work carried out by social services, relations with other agencies 
(e.g., employment, education, health), relations with Non-Governmental Organizations (NGOs) and associations, and significant practices and proposals

The focus groups (FG) allowed for a nuanced confrontation of different perceptions, also providing summary assessments on some relevant aspects. The sessions were scripted, although open debate was encouraged. A total of three focus groups were conducted with an average duration of $75 \mathrm{~min}$ (Table 1). The coding followed in order to identify the speeches of the different actors throughout the text: FG 1-SS.SS professionals (7); FG 2-employment service professionals, local third sector, etc. (7); FG 3-political representatives and organizers.

For the FG 1, we selected professionals in charge of the Cohabitation and Social Reintegration Program in the four centers studied and a professional who was dedicated to each of the other three programs (Information; Valuation and Orientation; Attention to Dependency; Social Cooperation and Volunteering). FG 2 was made up of professionals from the third sector who maintained direct coordination relationships with social entities located in each of the four zones; four of these informants belonged to national entities that act in zones, while the other three belong to local entities. Finally, FG 3 was formed by the political leader of each zone (the leader of one of the zones was not invited because he understood that there could be a conflict of interest).

Table 1. Coding of research participants.

\begin{tabular}{ccc}
\hline ID & Profile of Participants & $\mathbf{N}^{\mathbf{0}}$ Participants \\
\hline FG 1 & SS.SS professionals (between 25 and 58 years). & 7 \\
\hline FG 2 & $\begin{array}{c}\text { Employment service professionals, Local Third Sector (between 23 } \\
\text { and 47 years). }\end{array}$ & 7 \\
\hline FG 3 & Political representatives and organizers (35, 50 and 53 years). & 3 \\
\hline SOI 1 & Public sector politicians (woman, 54 years) & 1 \\
\hline SOI 2 & Third Sector Director (men, 37 years) & 1 \\
\hline SOI 3 & Direct intervention professionals (public sector) (woman, 27 years) & 1 \\
\hline SOI 4 & Direct intervention professionals (public sector) (woman, 40 years) & 1 \\
\hline SOI 5 & Direct intervention professionals (public sector) (men, 38 years) & 1 \\
\hline SOI 6 & Direct intervention professional (public sector) (woman, 57 years) & 1 \\
\hline SOI 7 & Direct intervention professional (third sector) (men, 44 years) & 1 \\
\hline SOI 8 & Direct intervention professional (third sector) (woman, 29 years) & 1 \\
\hline SOI 9 & Clients 1 (man, 50 years). & 1 \\
\hline SOI 10 & Clients 2 (woman, 25 years). & 1 \\
\hline SOI 11 & Clients 3 (man, 43 years) & 1 \\
\hline SOI 12 & Clients 4 (woman, 36 years) & 1 \\
\hline & Source: own elaboration. & \\
\hline
\end{tabular}

Both the interviews and focus groups were recorded, transcribed, and anonymized according to the informed consent of the participants. The transcriptions and observation memos were included in a database created with the qualitative analysis software ATLAS-ti. Clarifying the coding followed a semi-inductive approach, given that we started encoding around the study dimensions (e.g., normative, operative, discursive) though it was based on the constant comparison method [20].

For the initial (open) coding phase, 49 labels were identified, 29 of which were relevant to (1) the study objectives, (2) the existence of overlaps in the four cases studied, and (3) the emergence of code-related discourse in at least two of the three types of actors. In the application of the constant comparison method, a second (axial) codification of these 29 codes was carried out, from which we identified four codes that concentrated the highest levels of rooting. In Table 2, we showed the reader the code table that supports the analysis of the results: 
Table 2. Coding.

\begin{tabular}{|c|c|c|}
\hline Grouping Code & Specific Code or Label & Actors Incidents \\
\hline \multirow{9}{*}{$\begin{array}{l}\text { C.1. Mission and idea of } \\
\text { intervention }\end{array}$} & C.1.1. Role of the professional & Politicians/professionals \\
\hline & C.1.2. Dimension of the provider & Politicians/neighbors \\
\hline & C.1.3. Expectation of care & Politicians/neighbors \\
\hline & C.1.4. Solving or managing & Politicians/neighbors \\
\hline & C.1.5. Integrating or activating & Politicians/professionals \\
\hline & $\begin{array}{l}\text { C.1.6. Social orientation } \\
\text { or accompaniment }\end{array}$ & Politicians/neighbors/professionals \\
\hline & C.1.7. Social transformation & Neighbors/professionals \\
\hline & C.1.8. Beyond professional intervention & Politicians/neighbors/professionals \\
\hline & C.1.9. Problems or areas & Politicians/professionals \\
\hline \multirow{11}{*}{ C.2. Knowledge management } & $\begin{array}{l}\text { C.2.1. Conditioning factors } \\
\text { for intervention }\end{array}$ & Politicians/professionals \\
\hline & C.2.2. Knowledges/skills & Neighbors/professionals \\
\hline & C.2.3. Program analysis/evaluation & Politicians/professionals \\
\hline & C.2.4. Collaborative/relational work & Politicians/clients/professionals \\
\hline & C.2.5. Evaluation/quality & Politicians/professionals \\
\hline & C.2.6. Management staff & Politicians/clients/professionals \\
\hline & C.2.7. Permanent training & Politicians/professionals \\
\hline & C.2.8. Public expectations of the SS & Politicians/clients/professionals \\
\hline & C.2.9. Instrumental knowledge & Politicians/clients/professionals \\
\hline & $\begin{array}{l}\text { C.2.10. Modernization of } \\
\text { the administration }\end{array}$ & Politicians/professionals \\
\hline & C.2.11. Capital of knowledge & Politicians/clients/professionals \\
\hline \multirow{3}{*}{ C.3. Action Networking } & C.3.1. Leadership of local networks & Politicians/clients/professionals \\
\hline & C.3.2. Specialized actions & Politicians/clients/professionals \\
\hline & C.3.3. Integral actions & Politicians/clients/professionals \\
\hline \multirow{6}{*}{$\begin{array}{l}\text { C.4. Support and helping } \\
\text { relationship. }\end{array}$} & C.4.1. Professional assignment & Politicians/professionals \\
\hline & $\begin{array}{l}\text { C.4.2. Professional-customer } \\
\text { relationship }\end{array}$ & Politicians/clients/professionals \\
\hline & C.4.3. Inclusive efficiency of resources & Politicians/clients/professionals \\
\hline & $\begin{array}{l}\text { C.4.4. Continuity in the } \\
\text { support processes }\end{array}$ & Clients/professionals \\
\hline & $\begin{array}{l}\text { C.4.5. Communication and } \\
\text { reception context }\end{array}$ & Clients/professionals \\
\hline & C.4.6. Vocation/emotional connection & Clients/professionals \\
\hline
\end{tabular}

\section{Results}

Focusing on the analysis of the data, we observed that there was a high degree of agreement on the issues of concern pointed out by professionals, clients, and managers. This is undoubtedly influenced by the similarity of the characteristics of the population and the social context in which the different social service centers studied were located. However, in spite of agreeing on the same issues of concern, there were different perceptions and visions about them, and it was this contrast of perceptions that was the main area of interest in this article. 
In reviewing the codes that have emerged, the most coinciding codes focus on four issues, which allow for the identification of central axiomatic elements of concern shown by the different actors (Figure 2). The first group of issues, which is undoubtedly the most relevant in terms of the analysis of discourses, refers to the purpose, revealing the lack of a solid concept regarding the final mission of the SS. The fragility of this issue is the main determining factor of the other three issues: the format of basic processes of knowledge management (management instruments, relationship between professional management staff with direct attention, planning and evaluation, etc.); multilevel relations (between generalist and specialized levels, with other services such as health or education, with the community and with NGOs); and, finally, the helping relationship that is established between professional and client.

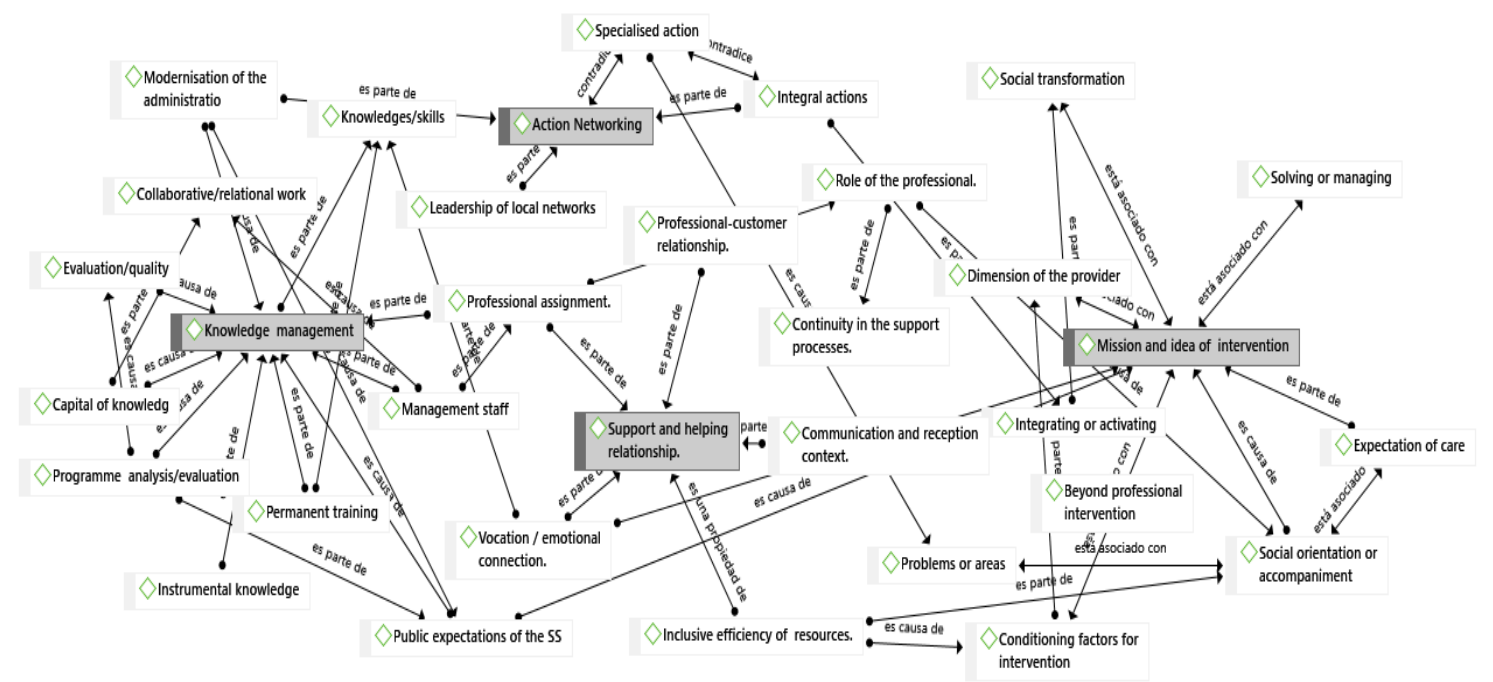

Figure 2. General code network. Source: own research.

The following sub-sections focus on the dense description [21] of these four groups of issues, explaining the central aspects of the analysis accomplished. We also use, as an illustrative element, some speeches extracted from the transcriptions, although these have a purely exemplary character of the ideas we present.

\subsection{Mission and Ideas Regarding the Role of the SS.SS}

The SS.SS are generally recognized as local social welfare institutions of a public and strictly professional nature. Their legitimacy lies in the fact that they are seen as a normatively regulated social right, which is why they are based on the idea that their work must go beyond the purely charitable and must be professionalized. The following quote shows this idea from the viewpoint of a client of SS.SS: "You know that you are in the administration, they help you because it is your right. When you go to Caritas (NGO) it is different, they are volunteers who help you because they want to" (SOI 12. Clients).

It is a fact that the objectives and contents of SS.SS are formally covered by regulations and laws. However, there is a clear tension between what the regulations say and the idea that the different local actors have what these services should ultimately do. Contributions in key informant interviews and discussion groups highlight this dysfunction between the norm and operational expectations. This issue is particularly important in the case of Andalusia: although the SS.SS regulation is the responsibility of the regional government, the management of the SS. centers corresponds to the local administration (town councils), which has a high level of autonomy to establish the organizational models, management systems, and the intervention model. Something that makes it very difficult for SS.

At the local-municipal level, we found that the vision of the operational role of the SS.SS was not uniform. Deepening the analysis of the codification of the interviews and discussion groups of the 
first group (C.1. Mission and idea of intervention) and we related some of them (C.1.2. Dimension of the provider; C.1.4. Solving or managing; C.1.5. Integrating or activating), we identified two visions that correspond to groups of interviewee profiles. The first one emphasizes the provider dimension, understanding that the role of professionals is (1) to solve problems or (2) to administer social benefits (both are characteristics of neighbors and politicians); the second one emphasizes the integrating or activating dimension, understanding that the intervention consists of (3) social orientation or (4) accompaniment processes (these visions are predominant among professionals).

From a normative point of view, the role of professional intervention in legislation and programming focuses on what we have called the integrating/activating dimension, as was reflected in Figure 1, and was also made explicit in the latest legislation regulating SS.SS [2]. The professional is a professional because of their ability to promote personal and contextual changes [22].

However, the fact that technicians and planners conceive an intervention of social transformation, while citizens and politicians prioritize the work of providers and problem managers, makes an essential difference to the public expectation of SS. This confrontation of expectations influences the daily life and conditions the contents of the actions of the SS: "For me a good professional is one who achieves things that help people improve their lives... for my (political) bosses a good professional is the first one to close a file" (FG 1).

The fragile awareness of the mission of the SS.SS makes it difficult to consolidate inclusive approaches, even if they are normatively explicit and assumed from the professional sphere. The lack of a uniform conception of the mission of the SS.SS is a specific element that does not occur, at least not as clearly, in other social policy systems, such as health or education in Spain [23]. In our opinion, this fact conditions all the other processes.

A second aspect refers to what the processes are. In the debate in FG 1, we identified a set of problems/scope that requires an inclusive intervention and that, as shown in Figure 3, are connected in a loop.

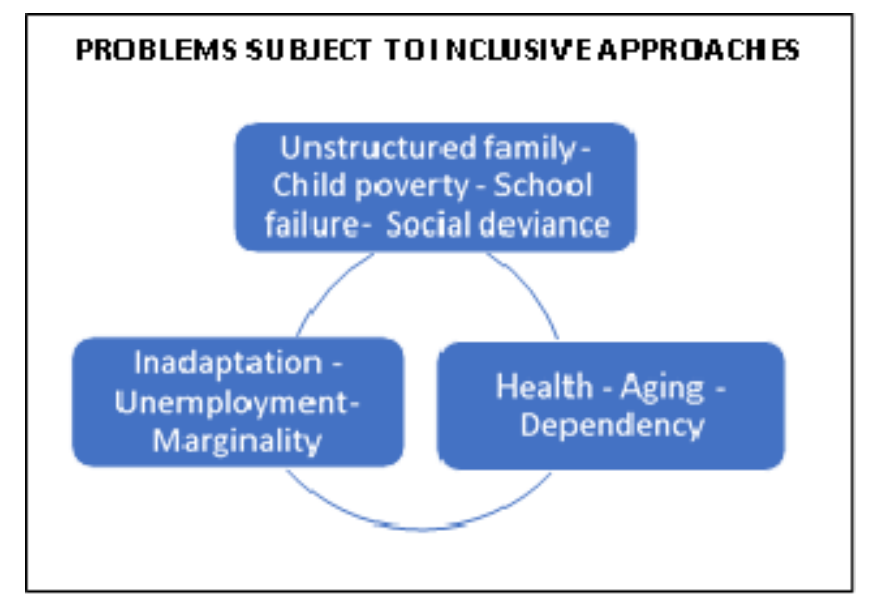

Figure 3. Problems subject to inclusive approaches. Source: own research.

This loop connection highlights the complexity and interconnection of different exclusionary processes. It is because of this complex nature of exclusion, which often requires specific solutions adapted to each person and each family that knowledge management issues become particularly relevant. These aspects, a concern above all for professionals, are dealt with in the following section.

\subsection{How to Manage Knowledge}

Should we improve people's lives or be good record managers? This question focuses on the main stressor of SS.SS professionals. In the analysis of the operative dimension, it is evident how, despite the inclusive objectives, different aspects hinder the intervention conditions on a day-to-day basis. The first 
and most prominent type of limits refer to questions of knowledge management; the main capital of professional intervention and a key aspect in blocking or promoting social innovations [24].

Direct care professionals understand that the management model implemented values, mainly their instrumental knowledge and the information generated by their action (the data, to be more specific). Although they have the power to analyze particular situations (cases with which they work), they hardly have any weight in the analysis of the programs, which remains in the hands of the techno-political staff, thus wasting a capital of knowledge in the evaluation of these policies. This vision is detected by analyzing some management processes.

The most visible is the information management system. The customer service record is organized through several computerized databases. The most important is the Unified System of Social Services Information (SIUSS, for its acronym in Spanish), which is a common tool for all SS.SS in Andalusia. However, as these are municipal management services, local administrations have developed other bases adjusted to specific needs. In some cases, these were integrated into SIUSS but in others they were duplicated.

As far as these systems are concerned, professionals point out two elements of weakness. The first regards the necessity to integrate the different sources of information in order to avoid loss of time due to recording data in duplicate or triplicate. The second, more strategically, relates to data management, which is usually carried out by the planning staff and has a marginal use for the evaluation of the intervention, as the following informant points out: "The technicians produce data, but then we do not participate in the analysis to know where we have to go..." (SOI 5. Professional).

Another type of process refers to internal coordination and evaluation. Professionals perceive a loss of collaborative work, what becomes clear when we see how in the four centers studied, meeting times (to coordinate, exchange information, etc.) have been replaced by online exchange systems. This loss of space also implies less collective knowledge, since for professionals, meeting spaces have an added value by allowing them to share knowledge, skills, etc. in a context of interaction: "Before we met weekly, we discussed complex cases... now if I have to recommend something to another colleague, I register in SIUSS. It is faster, but we also contrast less and there is less team feeling" (FG1); For me, team meetings are mostly formative, in the debate with colleagues one learns continuously" (SOI 4. Professional).

The evaluation also follows a similar scheme and, in addition, these evaluations are restricted to the specific task of SS.SS. There are no tools or spaces for shared evaluation among the various actors and levels of governance, which is essential when addressing complex objectives such as inclusion [21]. Finally, evaluation procedures are often almost exclusively based on the development of defined tools (forms, questionnaires, etc.) Procedures that are necessary but which, when used exclusively, once again waste a part of the knowledge that is generated by open reflection and a dense description of the problems [25]: "We make the report of the program, which they use to evaluate in the central services. We would like to participate more, to have moments to talk about things that are not in the forms" (SOI 8. Professional).

In other knowledge management processes, such as the permanent training of professionals or the definition of intervention protocols, the same perception emerges: the idea that work forms that do not have a relational and collaborative dimension have been implemented; and, also, that these forms are predefined by the techno-political staff, with an insufficient knowledge in contrast with the intervention technicians.

These weaknesses are marked by a policy of modernization of the administration implemented since the 1990s [26]. These measures, which came largely from the scope of the company, were adopted by the municipal administrations, sometimes in a non-reflective manner and without adapting to the peculiarities of SS.SS [27]. In other regions there was a review and improvement of knowledge management issues promoted by the regional administration. In the region of Andalusía, as in other regions of southern Spain, this is a matter that suffers a clear delay. 


\subsection{Relations in Action Networks}

There are matters regarding networks that condition the work of accompaniment in SS.SS, although it is another of its tasks. Professionals from other agencies that make up these local inclusion networks (education, health, employment, housing, and NGOs) value the ability to respond quickly and adapt to very different SS.SS situations. However, at the same time, they do not see these as an agency that leads the whole of resources of the territory for an integral intervention, but as collaborators in their respective spheres of action (FG 2). It is clear here how specialized interventions predominate over integral interventions, concentrating the relations between entities in the exchange of information about the cases, if not in the mere derivation of one service to another.

As an example, FG 2 describes the relation between SS.SS and Employment Insertion Services. The employment professionals state that they only intervene with the population with short-term insertion possibilities, referring the population that is not very employable to SS.SS. This practice is carried out without a specific work on both parts, and it stems from the cases with little chance of success in a natural way. The referral is usually done without relationship between professionals, sending directly to the client, sometimes with a written communication and rarely generating diagnoses or common action plans for employment SS.SS.

The leadership capacity of these local networks by the SS.SS focuses more on specific situations than on defining broad policies, such as the treatment of the school absenteeism within a neighborhood: "We have started a joint protocol for absenteeism, coordinated the work of schools, the police, juvenile prosecutor's office, and NGOs. With this, absenteeism has been reduced by 30\%" (SOI 2. Political).

Despite its ability to dynamize networks around these situations, it has not transcended to more global work environments locally.

\subsection{To Care for or to Accompany: Professional Vocation or Citizen's Right?}

The last group of limits refers directly to the context of relations between professionals and clients, in which emerges different effects that increase the difficulties of accompaniment.

One of them is the adjustment of the professional to the tasks that are carried out daily. The planning of daily work is very focused on the reception in the office (home visits or work in the street have lost importance as tools for intervention). In addition, schedules have concentrated on the morning, functioning more as a care office than as a SS.SS center: less social work and more administrative work is done, so the skills of these professionals are less necessary for SS.SS.

Discontinuities are another factor that blocks the accompaniment relationship between professional and client, but the main factor of discontinuity is the mismatch between the material aid and the accompanying processes: "You are working with a family and you consider a basic income to be useful, but the procedures and [the administration] take almost a year to be granted" (SOI 7. Professional).

Paradoxically, the administrative procedures designed in the regulations to facilitate inclusion are often not managed from the administrative side in terms of support. This logic of administrative management does not facilitate accompanying social work.

The host environment and the conditions for adequate professional-client communication, keys for a relationality of accompaniment [28,29], have also been mutating. In most of the offices visited, the professional-client relationship is produced on a rectangular table, with barriers such as differentiated seats and computers on the table. Some professionals resort to meeting at circular tables, but less frequently.

This daily routine produces a format of professional-client relationship oriented to the immediate, although this does not imply that the accompaniment has stopped.

From the observation made, four categories of attention can be seen. The first would be strictly one-off emergencies. The second, which is the great majority of the demands, is that of continuous attention to families who habitually attend, even for years, families with some level of chronification; however, this continuity in attention means that accompaniment is provided: "The families we have 
known for years sometimes come for emergency aid, sometimes for school matters, for the management of a basic income... but between one support and another we lose sight of them" (SOI 6. Professional).

Protective care (e.g., minors, gender violence) is a third group. Here, there is usually a more continuous and intense type of care, but one that is more guided by a crisis intervention model [30] than accompaniment to inclusion. Only some of the above situations can be classified as accompaniment care; the fourth group, in which professionals, overwhelmed by the daily demand, select those clients (mainly from groups 2 and 3) to generate accompaniment processes.

The professionals consider that the vocational aspects and the emotional connection with the client are more influential in the change from continuous attention to accompaniment, than the criteria of institutional and availability (of time and space). This is especially true when this connection allows for an improvement of the self-perception of the situation and generates realistic expectations.

Clients also know what they can get from each entity and from each professional, as many are expert clients: "I come (to SS.SS) for what they give me, but to help me (to find a job as a maid) I have gone to DESAL (a local NGO)" (SOI 10. Client).

This differentiation between giving (material benefits) and helping shows how clients use different tactics to be served by professionals that fit their expectations.

Observation makes it possible to affirm that the dynamics of accompaniment are produced, mainly because clients and professionals connect to each other rather than as a result of planning geared towards the guarantee of a subjective right.

\section{Discussion}

Returning to the question that guides this research (what kind of factors limit the adoption of inclusive approaches in SS.SS?), two groups of interacting elements can be identified. One refers to the sociopolitical context, the other to relational contexts and intervention.

\subsection{Contextual Factors. A Political Problem}

In the study of the case of Andalusia the political dynamics are observed, especially how the economic dependence has hindered the modernization of the SS.SS in areas with high rates of exclusion. This is not an isolated fact. The economic differences between regions, more intense in Spain and other Mediterranean countries, are joined [31] with the sustainability problems that affect social policies in Europe, as shown by works such as those of Huber et al. [32] and Küzel [33], which cause different levels of SS.SS development [12].

In addition, in the case of Andalusia, the social democratic governments of the last decades formulated regulations on inclusion without specifying the necessary resources for this: "In Andalusia we legislated a lot of social rights, but laws without a budget" (FG 3). This difference between legislation and practice generates pessimism and a certain skepticism, noticeable in interviews with citizens who doubt the practical effect of any legislation on inclusion.

The complementarity between local and regional administration in the provision of SS.SS is another significant factor. In the Andalusian municipalities there are two different types of welfare services: those that are managed directly by the regional administration (health, education, and employment) and those managed by the local administration and co-financed through subsidy programs between both governments [2]. The SS.SS is in the second type, with worse conditions of stability in its programs and professional staff, and less capacity to guarantee subjective rights [23]. As we have seen, this secondary position makes local network leadership very difficult. This situation is not an isolated one, as the work of Atkinson et al. [6], Ruíz et al. [34], and Means et al. [35], it is a dynamic that can be perceived both at European and local level. This coordinated leadership is more necessary in areas with high rates of exclusion, where there are much more demands than in other areas.

A third process of weakness occurs in a strictly local level. As we have already explained, in Andalusia there are 336 Social Services Centers managed by local administrations, 24 of which are in areas with high rates of exclusion. When planning SS.SS in each municipal administration, 
the diversity of approaches and practical visions on the role of these increases. As in other countries of late entry into the Welfare State [1], a good part of the local politicians did not overcome the welfare vision (FG 3) of pre-democracy municipal welfare services, "if we want to change SS.SS it would be necessary to invest in the training of councilors" (SOI 2. Politic). This perception influences the daily guidelines set for professionals [36]. In addition, sometimes local managers use SS.SS as a hinge on the political pressures received from socially demanding citizens [37], imposing contradictory directives on technical criteria.

These issues limit both the leadership of networks for inclusion and the development of methodology for accompaniment work.

\subsection{Relational Factors and Social Intervention Power and Knowledge}

Different theoretical works point out that the option for accompanying methodologies has gone beyond the technical discourse to the political, advocating a change that allows the passage of top-down responses to others in which customers have more prominence [38-40]. However, as Bruner [41] points out, it is frequent that these postulates do not form into practical decisions, remaining as desirable abstractions. We can affirm that this institutional behavior predominates in the studied case. This occurs, according to the technicians, due to two aspects: the lack of operational leadership on a day-to-day basis from the political side and from the directors of the centers; and, at the same time, the weak recognition of the skills to manage accompaniment practices that many professionals have.

Implementing such methodologies requires a review of power relations that modify the habitus [42], both in the intervention practices and in the institutions processes that develop them [24]. In the ongoing observation of SS.SS, it is appreciated that although there is no lack of will, there is also no solid awareness of the changes that each actor must make possible for this. Neither from politicians to experts, nor from these to clients. Therefore, paradoxically, it is intended to promote empowerment without reviewing the status quo and without adapting the devices for its new functionality.

The main area where this phenomenon is visible is in the management of technical and political knowledge for the intervention. This case shows how certain knowledge management policies adopted in SS.SS are better prepared to facilitate approaches focused on deficiencies than on capacities by giving priority to efficacy over efficiency, giving more value to information and data than to the knowledge, and the wisdom of each agent [43]. These policies weaken the shared knowledge, renouncing the power that generates collaborative forms [44]. These issues are particularly relevant in crisis contexts [45].

Yet this situation does not remain as such. It is also reproduced in the client-professional relationship [43] and, more specifically, in the relationship between customers and the organization in general. The programs, the professional commissions, even the physical space, are more prepared for the attention than for the interaction. We rarely intervene with groups of clients to share the situation, or we look for initiatives of self-support or mutual support. Therefore, the action of direct care professionals is also a poor promoter of collaboration.

In the attempts at social innovation, SS.SS take little advantage of non-material resources. In line with other works $[11,46]$, we see how the difficulty in collaboratively managing knowledge contributes to the loss of skills of professionals.

In the same way, the absence of these collaborative forms in the client-professional relationship entails the loss of useful information for innovation, which is provided by expert users [47]. Also renounced is the connection with another space of social innovation, that which the clients themselves produce autonomously in the form of informal networks, initiatives of reciprocity, etc. [48].

The loss of collaborative skills, in contexts of recentralization and privatization of care [45,49], also affect the disempowerment of SS.SS in its task with respect to local networks and the community in general, together with the factors already mentioned in the previous section. Community participation is managed as a tool for improving efficiencies among those involved, giving priority to forms of formal coordination (rather than co-management), aimed at reducing tensions [50]. Without questioning the value of this purpose, the work of community networks is not organized as strategic governance [51], 
nor with respect to third sector organizations that collaborate with SS.SS programs, and nor with respect to other welfare services, concentrating the energies in which [52] brings tactical practices.

Neither are community care approaches applied in the case study [35,45], the mere orientation towards the aforementioned reduction of tensions leaves no space for building networks in which to involve different actors in the territory (neighbors, volunteers, civic entities, informal groups, etc.). These two elements- the strategic governance and the development of community care networks-would help to improve the positioning of the SS.SS.

\section{Conclusions}

The adoption of a focus on strengths in SS.SS should not be thought of only in terms of clients, but of strengthening the skills of all the actors present in the inclusion processes.

For this reason, for the consolidation of accompanying methodologies, it is not enough to recover public investment and increase professionals, although it is essential. In addition to this, it is necessary to make a political commitment to social innovation in SS.SS, especially in relation to management environments. This innovation has to prioritize collaborative relationships between actors (politicians, technicians, clients), where the top-down (political-professional) and give-receive (professional-clients) logics lose weight in favor of more reciprocal modes of generation in the processes of diagnosis, planning, implementation, evaluation and formation of local inclusion policies.

As a main recommendation for policy planners and service managers, the approach of social service policy to accompanying models requires a reorganization of the current model. SS.SS needs to combine clear regulation at the regional level, with specific funding for the Cohabitation and Social Reintegration Program (currently, there is funding for all programs), with greater technical autonomy to develop genuine strategies adapted to each local reality, where each center has the capacity to establish its processes according to the achievement of objectives. This implies a different role for the political and institutional bodies, which logically have the monitoring and evaluation responsibilities, although they must focus more on inclusive impact than on strictly procedural issues. On the other hand, these SS.SS centers not only have the mission of organizing their institutional resources but also of acting as facilitators for the different agents that have an impact on the community in order to promote authentic support networks for vulnerable people and groups.

Author Contributions: Investigation, G.J.A. and A.G.P. All authors have read and agreed to the published version of the manuscript.

Funding: This research is funded by the State Program for the Promotion of Scientific and Technical Research of Excellence of the Ministry of Economy, Industry and Competitiveness of the Spanish Government, within the State Sub-Program for Knowledge Generation. The Project has funding of 42.073 euros. (Call 2017. Rf. CSO2017-85486-P)

Conflicts of Interest: The authors declare no conflict of interest. The funders had no role in the design of the study; in the collection, analyses, or interpretation of data; in the writing of the manuscript, or in the decision to publish the results.

\section{References}

1. Del Pino, E.; Pavolini, E. Decentralisation at a Time of Harsh Austerity: Multilevel Governance and the Welfare State in Spain and Italy Facing the Crisis. Eur. J. Soc. Secur. 2015, 17, 246-270. [CrossRef]

2. Defensor del Pueblo Andaluz. La Situación de los Servicios Sociales Comunitarios en Andalucía; DPA: Seville, Spain, 2005.

3. Itzhaky, H.; Bustin, E. Strengths and Pathological Perspectives in Community Social Work. J. Community Pract. 2002, 10, 61-73. [CrossRef]

4. Saleebey, D. The Strengths Perspective in Social Work Practice: Extensions and Cautions. Soc. Work. 1996, 41, 296-305. [CrossRef] [PubMed]

5. Barbier, J.C. Welfare to Work Policies in Europe: The Current Challenges of Activation Policies; Center D'études de L'emploi: Paris, France, 2001. 
6. Atkinson, A.B.; Guio, A.C.; Marlier, E. Monitoring Social Inclusion in Europe; Eurostar, Statistical Books Collection: Luxembourg, 2017; Available online: https://ec.europa.eu/eurostat/web/products-statisticalbooks/-/KS-05-14-075 (accessed on 22 October 2020).

7. Elez, P.D.L.P. La intervención en Trabajo Social desde la perspectiva de las fortalezas. Cuad. de Trab. Soc. 2011, 24, 155-163. [CrossRef]

8. Consejería de Asuntos Sociales. Plan Andaluz de Inclusión Social 2003-2006; Junta de Andalucía: Seville, Spain, 2003; Available online: https://www.observatoriodelainfancia.es/ficherosoia/documentos/452 d_Plan-Andaluz-de-Inclusion-Social-2003-2008.pdf (accessed on 22 October 2020).

9. Raya, E.; Caparrós, N. Acompañamiento como metodología de Trabajo Social en tiempos de cólera. Cuad. Trab. Soc. 2014, 27, 81-91.

10. Eransus, B.P. El acompañamiento como herramienta en la lucha contra la exclusión. Doc. Soc. 2004, 135, 89-108.

11. Echegaray, A.H. Los riesgos en la profesionalización del Trabajo Social en España. Cuad. Trab. Soc. 2018, 31, 139-152. [CrossRef]

12. Ortega-Galán, Á.M.; Ortiz-Amo, R.; Andina-Diaz, E.; Ruiz-Fernández, M.D. The Sustainability of Public Social Services: A Qualitative Study. Sustainability 2020, 12, 3860. [CrossRef]

13. Memoria del Plan Concertado de Prestaciones Básicas de Servicios Sociale. 2018. Available online: https://www.mscbs.gob.es/ssi/familiasInfancia/ServiciosSociales/MemoriasPlanConcertado.htm (accessed on 22 October 2020).

14. Coller, X. Estudio de Casos; CIS: Madrid, Spain, 2005.

15. Carrasco-Campos, A.; Martínez, L.C.; Moreno, A. Revisión crítica de la medición del bienestar desde una perspectiva interdisciplinar. Hacia una propuesta de indicadores subjetivos y espaciales. Prism. Soc. Rev. Cienc. Soc. 2013, 11, 91-122.

16. González, A.; Jaraíz, G. Las políticas de inclusión social en Andalucía desde la perspectiva discursiva y lexicométrica. Un análisis comparativo del discurso técnico-político. Empiria Rev. de Metodol. de las Cienc. Soc. 2020, 45, 75-111. [CrossRef]

17. Morel, N.; Palier, B.; Palme, J. (Eds.) Social investment: A paradigm in search of a new economic model and political mobilisation. In Towards a Social Investment Welfare State? Ideas, Policies and Challenges; The Policy Press: Chicago, IL, USA, 2012.

18. Montgomery, P.; Bailey, P.H. Field notes and theoretical memos in grounded theory. West. J. Nurs. Res. 2007, 29, 65-79. [CrossRef] [PubMed]

19. Denzin, N.K. The Research Act. A Theoretical Introduction to Sociological Methods; Aldine Transaction: New Brunswich, NJ, USA, 2017; ISBN 978-0-202-36248-9.

20. Harris, T. Grounded theory. Nurs. Stand. 2015, 29, 32-39. [CrossRef] [PubMed]

21. Geertz, C. The Interpretation of Cultures; Basic Books: New York, NY, USA, 1973; ISBN 9780465093564.

22. Chambers, R. Ideas for Development; Routledge: London, UK, 2013.

23. Fantova, F. Sistemas Públicos de Servicios Sociales; Deusto: Bilbao, Spain, 2008; ISBN 8498301483.

24. Mulgan, G. The Process of Social Innovation. Innov. Technol. Gov. Glob. 2006, 102, 145-162. [CrossRef]

25. Nastasi, B.K.; Hitchcock, J. Challenges of Evaluating Multilevel Interventions. Am. J. Community Psychol. 2009, 43, 360-376. [CrossRef] [PubMed]

26. Rodríguez, J. La sociedad del conocimiento en la administración pública. Rev. Aragonesa de Adm. Pública 2004, 22, 219-232.

27. Ruiz, E.; Jaraíz, G.; Cordero, G. Gestión del Conocimiento en Servicios Sociales. Sociol. del Trab. 2009, 66, 3-29.

28. Wertsch, J. Voices of the Mind: A Sociocultural Approach to Mediated Action; Harvard University Press: Cambridge, MA, USA, 1991; ISBN 9780674943049.

29. Jaraíz, G.; González, A. The impact of local inclusion policies on disadvantaged urban areas: Perceptions in the case of Andalusia. Investig. Reg. J. Reg. Res. 2019, 44, 47-62.

30. Payne, M. Modern Social Work Theory, 4th ed.; Oxford University Press: Oxford, UK, 2016; ISBN 978-0-19-061524-6.

31. Jurado, A.; Pérez-Mayo, J. Construction and Evolution of a Multidimensional Well-Being Index for the Spanish Regions. Soc. Indic. Res. 2011, 107, 259-279. [CrossRef]

32. Huber, E.; Niedzwiecki, S. Mudanças nos sistemas de proteção social no contexto de transformações das economias políticas desde os anos 1980. Cienc. e Saude Coletiva 2018, 23, 2085-2094. [CrossRef]

33. Künzel, S. The local dimension of active inclusion policy. J. Eur. Soc. Policy 2012, 22, 3-16. [CrossRef] 
34. Ruiz, E.; González, A.; Sánchez, J.A. Profesionales frente a la intervención participativa. Comunicación y Dimensión Subjetiva. Gaz. de Antropol. 2012, 28, 6.

35. Means, R.; Richards, S.; Smith, R. Community Care: Policy and Practice, 4th ed.; Macmillan: Bakingstoke, UK, 2008; ISBN 9680230006744.

36. Miranda, M. De la Caridad a la Ciencia. Pragmatismo, Interaccionismo Simbólico y Trabajo Social; Mira Editores: Zaragoza, Spain, 2004.

37. Finn, D. Welfare to Work: The local dimension. J. Eur. Soc. Policy 2000, 10, 43-57. [CrossRef]

38. Cornwall, A. Putting partnership into practice: Participatory wellbeing assessment on a south Londres housing State. Health Expect. 2003, 6, 30-43. [CrossRef] [PubMed]

39. Montero, M. Hacer Para Transformar. El método de la Psicología Comunitaria; Paidós: Buenos Aires, Argentina, 2012; ISBN 950-12-4535-7.

40. Tritter, J.; McCallum, A. The snakes and ladders of user involvement: Moving beyond Arnstein. Health Policy 2006, 76, 156-168. [CrossRef] [PubMed]

41. Bruner, J. A Study of Thinking; Routledge: London, UK, 2017; ISBN 9780887386565.

42. Bourdieu, P. El Sentido Práctico; Siglo XXI: Barcelona, Spain, 2008; ISBN 978-323-1302-8.

43. Wolton, D. Communication. Hermès Cogn. Comun. Polit. 2018, 80, 272-279. [CrossRef]

44. Runesson, U.; Gustafsson, G. Sharing and developing knowledge products from Learning Study. Int. J. Lesson Learn. Stud. 2012, 1, 245-260. [CrossRef]

45. Redondo-Sama, G.; Matulic, V.; Pascual, A.M.; De Vicente, I. Social Work during the COVID-19 Crisis: Responding to Urgent Social Needs. Sustainability 2020, 12, 8595. [CrossRef]

46. Kim, H.; Stoner, M. Burnout and Turnover Intention among Social Workers: Effects of Role Stress, Job Autonomy and Social Support. Adm. Soc. Work. 2008, 32, 5-25. [CrossRef]

47. Lamb, R.; Kling, R. Reconceptualizing Users as Social Actors in Information Systems Research. MIS Q. 2003, 27, 197. [CrossRef]

48. Moulaert, F.; Swyngedouw, E.; Martinelli, F.; González, S. Can Neighbourhoods Save the City? Community, Development and Social Innovation; Routledge: London, UK, 2010; ISBN 978-0415485883.

49. Jaspers, S.; Steen, T. Realizing public values: Enhancement or obstruction? Exploring value tensions and coping strategies in the co-production of social care. Public Manag. Rev. 2018, 21, 606-627. [CrossRef]

50. Gustafsson, U.; Driver, S. Parents, Power and Public Participation: Sure Start, an Experiment in New Labour Governance. Soc. Policy Adm. 2005, 39, 528-543. [CrossRef]

51. Luke, B.; Barraket, J.; Eversole, R. Measurement as legitimacy versus legitimacy of measures: Performance evaluation of social Enterprise. Qual. Res. Account. Manag. 2013, 10, 234-258. [CrossRef]

52. De Certeau, M. La Invención de lo Cotidiano. Artes de Hacer; Universidad Iberoamericana: Mexico City, México, 2000; ISBN 978-968-859-259-5.

Publisher's Note: MDPI stays neutral with regard to jurisdictional claims in published maps and institutional affiliations.

(C) 2020 by the authors. Licensee MDPI, Basel, Switzerland. This article is an open access article distributed under the terms and conditions of the Creative Commons Attribution (CC BY) license (http://creativecommons.org/licenses/by/4.0/). 